\title{
ACTIVITY SALIVARY BACTERIA OF ACUTE LYMPHOBLASTIC LEUKEMIA CHILDREN IN CHEMOTHERAPY PHASE
}

\author{
ALIYAH ABDUL MUTHALIB, SARWORINI B.BUDIARDJO*, MARGARETHA SUHARSINI \\ Department of Pediatric Dentistry, Faculty of Dentistry, Universitas Indonesia, Jakarta - 10430, Indonesia. \\ Email: Sarworinibagio@yahoo.com
}

Received: 24 October 2017, Revised and Accepted: 22 November 2017

ABSTRACT

Objective: The objective of this study was to investigate the differences activity of salivary Streptococcus mutans bacteria in children suffer acute lymphoblastic leukemia (ALL) in phase of chemotherapy, induction, intensification/consolidation, and maintenance.

Methods: This study was a laboratory observational, and cross-sectional method, conducted 19 ALL children in phase of chemotherapy, induction, intensification/consolidation, and maintenance. $2 \mathrm{~mm}$ of dental plaque was collected from mesiobuccal first permanent molar and incubated for $48 \mathrm{~h}$ at $37^{\circ} \mathrm{C}$, and the bacterial activity of $S$. mutans measured by Cariostat.

Results: Odds ratio analysis among chemotherapy phase of induction, intensification/consolidation, and maintenance is not significant (p>0.05) differences.

Conclusion: The highest activity bacteria of $S$. mutans were found in the induction phase.

Keywords: Activity bacteria, Streptococcus mutans, ALL, Chemotherapy phase.

(C) 2018 The Authors. Published by Innovare Academic Sciences Pvt Ltd. This is an open access article under the CC BY license (http://creativecommons. org/licenses/by/4. 0/) DOI: http://dx.doi.org/10.22159/ajpcr.2018.v11i3.23274

\section{INTRODUCTION}

Acute lymphoblastic leukemia (ALL) is a heterogeneous hematologic disease of malignancy characterized by the proliferation of immature lymphoid cells in bone marrow, peripheral blood, and other organs [1-3].

The main therapy or standard of management of ALL is chemotherapy. Chemotherapy treatments are divided into three phases, namely, the induction, the intensification/consolidation, and the maintenance. One of the side effects of chemotherapy treatment can affect the balance of the body in general and the oral health such as dry mouth, aphthae, gingivitis, and dental caries [4-7].

Data on caries bacterial activity of Streptococcus mutans in children with ALL in Indonesia does not yet exist. Therefore, a study is needed to determine the activity of $S$. mutans bacteria in children suffering from ALL. Early detection with known $S$. mutans high bacterial activity in children with ALL can reduce morbidity and other complications that interfere with dental and oral health when undergoing anticancer therapy [8-10]. This fact has fascinated the writer to delve more deeply into the investigation of the activity of $S$. mutans bacteria in ALL children who undergoing chemotherapy phase.

\section{METHODS}

Examination of $S$. mutans bacteria activity using Cariostat media from Sankin Company, Japan. Plaque sampling was conducted at around
10:00-12:00 pm with the method of swab. The swab is done by applying a sterile swab cotton available on Cariostat packaging. The swab is applied to the cervical region of the first molars of the left upper jaw to the right upper right molar teeth, in children with ALL. Then, the cotton swab is inserted into the Cariostat ampoule that has been labeled demographic data and closed tightly. Cariostat is then inserted in a media transportation container for transport to the laboratory. Furthermore, incubation of Cariostat ampoule was done in incubator with temperature $37^{\circ} \mathrm{C}$ for $48 \mathrm{~h}$

Cariostat classification results are grouped according to chemotherapy, induction, intensification/consolidation, and maintenance phases. Then, the data were analyzed using Chi-square test with $\mathrm{p}<0.05$ significance. This analysis also continued with odds ratio (OR) test to see the proportion of each phase of chemotherapy.

\section{RESULTS}

The research has been done at Dharmais Hospital, Jakarta. From 40 patients of ALL were obtained this following result: From the cross-tabulation data show $S$. mutans bacteria activity in induction, intensification/consolidation, and maintenance phase are 54.5\%, $45.4 \%$, and $44.4 \%$, respectively. The result of analysis using Chi-square statistic test indicates the unsignificant difference between each chemotherapy phases of ALL children with classification of bacterial activity of $S$. mutans Cariostat, $\mathrm{p}=0.304(\mathrm{p}>0.05)$ (Table 1$)$.

Table 1: Differences of $S$. mutans bacterial activity between chemotherapy phases induction, intensification/consolidation phase

\begin{tabular}{|c|c|c|c|c|c|}
\hline \multirow[t]{2}{*}{ Phase } & \multicolumn{5}{|c|}{ Activity bacteria S. mutans n (\%) } \\
\hline & Less active & Active & Very active & Total & $\mathbf{p}$ \\
\hline \multicolumn{6}{|l|}{ Phase } \\
\hline Induction & $4(36.3)$ & $1(9,1)$ & $6(54.5)$ & 11 & \\
\hline Intensification/Consolidation & $3(27.2)$ & $5(45.4)$ & $3(27.2)$ & 11 & \\
\hline Maintenance & $8(44.4)$ & $5(27.8)$ & $5(27.8)$ & 18 & \\
\hline
\end{tabular}

$\chi^{2}=4.844$. S. mutans: Streptococcus mutans 
Table 2: Analysis OR between activity bacteria $S$. mutans in induction, intensification/consolidation, and maintenance phase

\begin{tabular}{lllll}
\hline Phase & \multicolumn{4}{l}{ Bacteria activity of $\boldsymbol{S}$. mutans } \\
\hline Phase & & Less active-active & Less active-very active & Active-very active \\
\hline Induction-consolidation & $\mathrm{OR}$ & 6.667 & 0.667 & 0.001 \\
& $\mathrm{p}$ & 0.155 & 0.697 & 0.077 \\
Consolidation-maintenance & $\mathrm{OR}$ & 0.375 & 1.667 & 0.625 \\
Induction-maintenance & $\mathrm{p}$ & 0.290 & 0.597 & 0.637 \\
& $\mathrm{OR}$ & 2.500 & 0.417 & 0.417 \\
\hline
\end{tabular}

OR: Odds ratio, p<0.05: Significant. S. mutans: Streptococcus mutans

From OR analysis between Cariostat classification with chemotherapy phase of induction, intensification/consolidation, and maintenance is not significant $(\mathrm{p}>0.05)$ (Table 2$)$.

\section{DISCUSSION}

ALL is a cancer that begins as a child and is a malignant disease that can lower the immune system even can cause death [4-6]. The severity of cancer is not only caused by the disease itself but can also be aggravated in the presence of secondary disease due to disease elsewhere. Treatment of ALL disease there are several stages according to the operation procedure of treatment, namely: Induction phase, intensification/consolidation phase, and maintenance phase [7-9]

Result of research of Streptococcus mutans bacteria activity has been done on child of Acute Lymphoblastic Leukemia in chemotherapy phase shows that bacterial activity of Streptococcus mutans is high on induction phase. While in the other classification of the findings of research results of $S$. mutans bacteria activity in the phase of induction seen the highest highly classified very active (54.5\%). In the phase of intensification/consolidation of the highest $S$. mutans actively classified activity (45.4\%), and at the highest maintenance phase of $S$. mutans was classified actively (44.4\%). Hence, in this study seen a decrease in the classification of bacterial activity from the onset of chemotherapy in the phase of induction and continued into the phase of intensification/ consolidation, and the maintenance phase $[9,10]$.

From the OR analysis table, no significance was found, but from the analysis of each chemotherapy phase with $S$. mutans bacterial activity can be concluded the OR induction/consolidation phase with activity $S$. mutans active and highest active. This means induced induction/ consolidation of $S$. mutans bacteria activity is highest when compared to the phase of induction and maintenance, followed by the phase of intensification/consolidation and maintenance.

The ability of adhesion of $S$. mutans on tooth surfaces when forming biofilms is directly related to some antigens. The result of glucose metabolism is lactic acid which is the main end product of glycolysis process with $\mathrm{pH}$ which is low [11-13]. The results of the research have found high activity of $S$. mutans bacteria, especially in the induction phase, so the possibility of caries in the future will increase [14-17]

The sensitivity of the bacterial $S$. mutans to detect dental caries test in children is reported to be $98 \%[18,19]$. This method can be applied to small children or difficult to treat patients and does not require specialized knowledge and tools. Use of Cariostat can be done both in private practice and as a screening tool in the wider community. In the case of patients suffering from ALL, it is beneficial because this method can be seen both directly by both the doctor and the patient and can also be prevented immediately $[20,21]$. With the knowledge of $S$. mutans bacteria activity is high, then prevention can be done such as cleaning the oral cavity is better and controlled, especially in the phase of induction [20,21].

\section{CONCLUSION}

From the results of research on $S$. mutans bacteria activity that has been done, it can be concluded, the need for special attention in patients with ALL, since dental and mouth health is very important, especially the possibility of secondary occurrence of infection. However, due to the lack of protocol equivalent for leukemia patients who will and are undergoing treatment, then maintaining oral hygiene becomes one of the reasons that need attention. Therefore, it is necessary to provide an appeal and cooperation between pediatric and blood dentist specialist doctors to include oral and dental health protocols as an integrated cancer treatment countermeasures.

\section{ACKNOWLEDGEMENT}

The Publication of the manuscript is supported by Universitas Indonesia in 2017. This study was designed, conducted, and coordinated by Professor Sarworini B. Budiardjo and Professor Margaretha Suharsini as the principal investigator, provided conceptual and ethical guidance for all aspect of the project. Aliyah Abdul Muthalib performed, analyzed the data, and write the manuscript.

\section{CONFLICT OF INTEREST}

There is no conflict of interest.

\section{REFERENCES}

1. Pui CH, Robison LL, Lock AT. Acute lymphoblastic leukemia. Lancet 2008;371:1030-43.

2. Gupta M, Dahiya J, Marwaha RK, Dureja H. Therapies in cancer treatment: An overview. Int J Pharm Pharm Sci 2015;7:1-9.

3. Antony A, Joel JJ, Shetty J, Umar NF. Identification and analysis of adverse drug reactions associated with cancer chemotherapy in hospitalized patients. Int J Pharm Pharm Sci 2016;8:448-51.

4. Hunger SP, Lu X, Devidas M, Camitta BM, Gaynon PS, Winick NJ, et al. Improved survival for children and adolescents with acute lymphoblastic leukemia from 1990-2005: A report from the Children's Oncology Group. J Clin Oncol 2012;30:1663-9.

5. Simanjorang C, Kodim N, Tehuteru E. Difference in survival of 5 years old patient with acute lymphoblastic leukemia and acute myeloblastic leukemia in Dharmais Cancer Hospital, Jakarta, 1997-2008. Indones J Cancer 2013;7:15-21

6. Azher U, Shiggaon N. Oral health status of children with acute lymphoblastic leukemia undergoing chemotherapy. Indian J Dent Res 2013;24:523.

7. Rimulo AL, Ferreira MC, Abreu MH, Aguirre-Neto JC, Paiva SM. Chemotherapy-induced oral mucositis in a patient with acute lymphoblastic leukaemia. Eur Arch Paediatr Dent 2011;12:124-7.

8. Çubukçu ÇE, Günes AM. Caries experience of leukemic children during intensive course of chemotherapy. J Clin Pediatr Dent 2007;32:155-8.

9. Thibodeau EA, O'Sullivan DM. Salivary mutans streptococci and caries development in the primary and mixed dentitions of children. Community Dent Oral Epidemiol 1999;27:406-12.

10. Thenisch NL, Bachmann LM, Imfeld T, Leisebach Minder T, Steurer J. Are mutans streptococci detected in preschool children a reliable predictive factor for dental caries risk? A systematic review. Caries Res 2006;40:366-74

11. Widiaskara IM, Permono B, Ugrasena IDG, Ratwita M. Luaran pengobatan fase induksi pasien leukemia limfoblastik akut pada anak di Rumah Sakit Umum Dr. Soetomo Surabaya. Sari Pediatri 2010;12:128-34

12. Hasle H. Pattern of malignant disorders in individuals with down's syndrome. Lancet Oncol 2001;2:429-36.

13. Eden T. Aetiology of childhood leukaemia. Cancer Treat Rev 
2010;36:286-97.

14. Buffler PA, Kwan ML, Reynolds P, Urayama KY. Environmental and genetic risk factors for childhood leukemia: Appraising the evidence. Cancer Invest 2005;23:60-75.

15. Donadieu J, Auclerc MF, Baruchel A, Leblanc T, Landman-Parker J, Perel Y, et al. Critical study of prognostic factors in childhood acute lymphoblastic leukaemia: Differences in outcome are poorly explained by the most significant prognostic variables. Fralle group. Frech acute lymphoblastic leukemia study group. Br J Haematol 1998;102:729-39.

16. Windiastuti E. Childhood acute leukemia: Cipto Mangunkusumo Hospital experiences. Medan: Presented in Perhimpunan Hematologi dan Transfusi Darah Indonesia; 2011.

17. Yeoh AE, Tan D, Li CK, Hori H, Tse E, Pui CH. Management of adult and paediatric acute lymphoblastic leukaemia in Asia: Resourcestratified guidelines from the Asian Oncology Summit 2013. Lancet Oncol 2013; 14:508-23

18. Cooper SL, Brown PA. Treatment of pediatric acute lymphoblastic leukemia. Pediatr Clin North Am 2015;62:61-73

19. Cortes JE, Kantarjian HM. Acute lymphoblastic leukemia. A comprehensive review with emphasis on biology and therapy. Cancer $1995 ; 76: 2393-417$

20. Pui CH, Evans WE. Acute lymphoblastic leukemia. N Engl J Med 1998:339:605-15.

21. Zhang XL, Komada Y, Chipeta J, Li QS, Inaba H, Azuma E, et al. Intracellular cytokine profile of $\mathrm{T}$ cells from children with acute lymphoblastic leukemia. Cancer Immunol Immunother 2000;49:165-72. 